\title{
The effect of altering the mechanical loading environment on the expression of bone regenerating molecules in cases of distraction osteogenesis
}

\author{
Mohammad M. Alzahrani 1,2, Emad A. Anam ${ }^{1,3}$, Asim M. Makhdom ${ }^{1,3}$, Isabelle Villemure ${ }^{4,5}$ and \\ Reggie Charles Hamdy ${ }^{1 *}$
}

${ }^{\prime}$ Division of Orthopaedic Surgery, Shriners Hospital for Children, Montreal Children Hospital, McGill University, Montreal, OC, Canada

2 Department of Orthopaedic Surgery, University of Dammam, Dammam, Saudi Arabia

${ }^{3}$ Department of Orthopaedic Surgery, King Abdulaziz University, Jeddah, Saudi Arabia

${ }^{4}$ Department of Mechanical Engineering, École Polytechnique de Montreal, Montreal, QC, Canada

${ }^{5}$ Sainte-Justine University Hospital Center, Montreal, QC, Canada

\section{Edited by:}

Jonathan H. Tobias, University of

Bristol, UK

\section{Reviewed by:}

Bronwen Evans, Cardiff University, UK Lee B. Meakin, University of Bristol, UK

\section{*Correspondence:}

Reggie Charles Hamdy, Division of Orthopaedic Surgery, Shriners Hospital for Children, McGill University, 1529 Cedar Avenue, Montreal, QC H3G 1A6, Canada e-mail:rhamdy@shriners.mcgill.ca
Distraction osteogenesis (DO) is a surgical technique where gradual and controlled separation of two bony fragments following an osteotomy leads to the induction of new bone formation in the distracted gap. DO is used for limb lengthening, correction of bony deformities, and the replacement of bone loss secondary to infection, trauma, and tumors. Although DO gives satisfactory results in most cases, one major drawback of this technique is the prolonged period of time the external fixator has to be kept on until the newly formed bone consolidates thus leading to numerous complications. Numerous attempts at accelerating bone formation during DO have been reported. One specific approach is manipulation of the mechanical environment during DO by applying changes in the standard protocol of distraction. Attempts at changing this mechanical environment led to mixed results. Increasing the rate or applying acute distraction, led to poor bone formation in the distracted zone. On the other hand, the addition of compressive forces (such as weight bearing, alternating distraction with compression or by over-lengthening, and then shortening) has been reported to increase bone formation. It still remains unclear why these alterations may lead to changes in bone formation. While the cellular and molecular changes occurring during the standard DO protocol, specifically increased expression of transforming growth factor- $\beta 1$, platelet-derived growth factor, insulin-like growth factor, basic fibroblast growth factor, vascular endothelial growth factor, and bone morphogenic proteins have been extensively investigated, the literature is sparse on the changes occurring when this protocol is altered. It is the purpose of this article to review the pertinent literature on the changes in the expression of various proteins and molecules as a result of changes in the mechanical loading technique in DO and try to define potential future research directions.

Keywords: mechanical loading, growth factor, distraction osteogensis, bone regeneration, bone regenerating molecule

\section{INTRODUCTION}

Distraction osteogenesis (DO) is a surgical technique first described by the Russian physician Ilizarov in the early 1950s $(1,2)$. This technique consists of performing an osteotomy to a bone that needs to be lengthened followed by gradual and controlled distraction of the two ends of the osteotomized bone. These mechanical forces of distraction lead to the induction and formation of new bone in the distracted gap (Figures 1 and 2) $(1,2)$. When the desired amount of lengthening is reached, the distraction is stopped but the external fixator is kept on until the newly formed bone in the distracted gap consolidates and becomes strong enough to withstand external forces after removal of the external fixator without bending or fracturing. The surgical technique of DO involves several temporal phases outlined below (3).

\section{LATENCY PHASE}

The latency phase starts immediately following the osteotomy and lasts between 5 and 7 days. It allows the formation and organization of the hematoma and facilitates the recruitment of inflammatory cells and mesenchymal stem cells (4). This stage resembles the acute stage of fracture healing, including hematoma formation, immediate inflammatory response, and subsequent differentiation of stem cells into chondrocytes and osteoblasts (4).

\section{DISTRACTION PHASE}

In this phase, following the latency period, distraction of the two bone segments is started at a specific rate and rhythm of $1.0 \mathrm{~mm}$ a day, divided into four increments. This protocol was shown experimentally and clinically - by Ilizarov to be the optimal rate and rhythm of distraction for bone formation. Higher rates of 


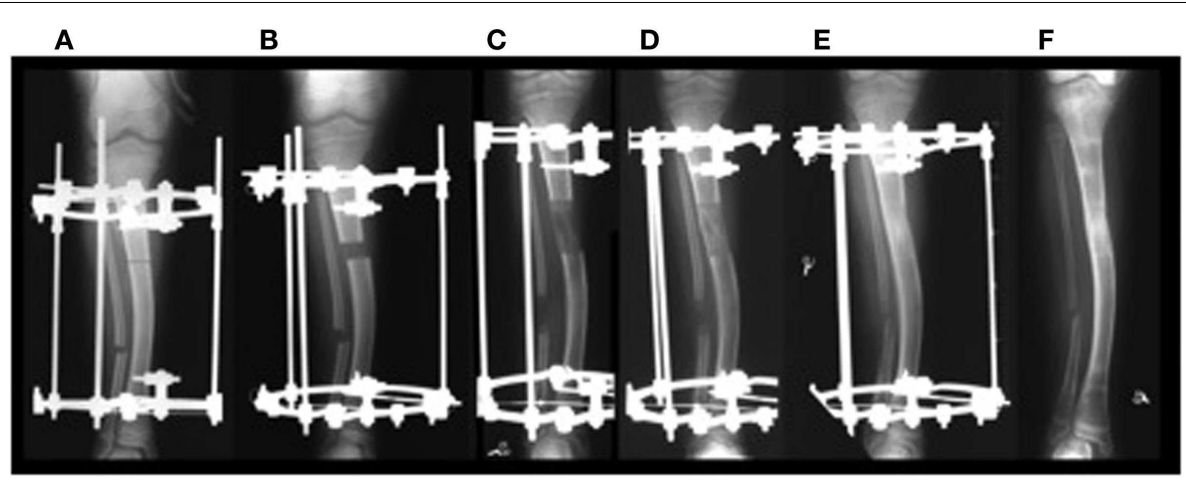

FIGURE 1 | (A) Application of distractor; (B) start of distraction; (C) end of distraction; (D,E) consolidation phase without any distraction until bone in the distraction gap consolidates; (F) removal of distractor. (C2012 Hamdy et al. (7).

distraction lead to poor or delayed regenerate bone formation while slower rates of distraction lead to premature consolidation (3). This phase is characterized by the formation of a radiolucent central fibrous interzone (FIZ) in the middle of the distracted gap (Figure 2). The fibroblast cells and collagen fibers are arranged longitudinally along the axis of distraction. In addition, one of the hallmarks of this phase is formation of new blood vessels with intense angiogenesis, neoangiogenesis, recruitment of osteoblasts, and new bone formation (5).

\section{CONSOLIDATION PHASE}

Once the desired amount of lengthening is obtained, distraction ceases, and the newly formed bone gradually bridges the gap between the two ends of the osteotomy (Figure 2). This new regenerate bone arises from the periosteum (hence, the importance of avoiding damage to the periosteum), the medullary canal, and the surrounding soft tissues (6). This phase is the longest phase in DO, about 1 month for each centimeter lengthened (1). In addition, it lasts until the newly formed bone in the distracted gap becomes biomechanically strong enough to allow removal of the fixator.

\section{ADVANTAGES OF DO OVER OTHER TECHNIQUES OF BONE REGENERATION}

Distraction osteogenesis is widely considered the best in vivo tissue engineering and has numerous advantages over other bone graft techniques, such as autografts, allografts, vascularized fibular grafts, and various artificial bone substitutes (7). With the technique of DO, very large and almost unlimited amounts of new bone can be generated and this newly formed bone is vascularized and of the same micro and macrostructure as the native bone. Furthermore, DO leads to the generation of new bone in a reproducible and predictable manner. One other major advantage of DO is the simultaneous regeneration and lengthening of all soft tissues surrounding the lengthened bone, including skin, subcutaneous tissues, blood vessels, nerves, and muscles (8).

\section{CLINICAL APPLICATIONS OF DO}

Nowadays, the technique of DO is widely used worldwide in the management of numerous orthopedic conditions including gradual correction of bony deformities, limb lengthening, and management of bone loss secondary to infection, trauma, and tumors (Figure 3) (7,9). Currently, this technique has been applied in maxillofacial surgery for mandibular lengthening and in the treatment of craniofacial deformities (10). DO has also gained popularity in the field of dental surgery (11-13).

\section{PROBLEMS ASSOCIATED WITH DO}

Although DO gives satisfactory results in most cases, one of the drawbacks of this technique is the prolonged length of time the external fixator has to be kept in place until the newly formed bone in the distracted gap consolidates. For every centimeter lengthened, the fixator has to be kept in place for about a month. For example, a child undergoing a $6.0 \mathrm{~cm}$ lengthening will require the fixator to be kept in place for about 6 months. This prolonged length of time during which the fixator is kept in place, may increase the risk of complications, such as pin site infections, pain, discomfort, and psychological complications (Figure 4) $(14,15)$.

Numerous methods have been described in an attempt to accelerate the consolidation of the newly formed bone and hence allow early removal of the fixator (16). Most of these techniques are invasive and involve the local application of substances such as osteogenic growth factors, allografts, autografts, mesenchymal stem cells, various synthetic bone substitutes (such as TCP - tricalcium phosphates), the systemic application of bone stimulating pharmacological agents or the use of external stimulation such as electromagnetic fields (17).

One area that has been surprisingly less extensively investigated in this context is the mechanical loading environment in DO and whether changes in this mechanical environment during the process of DO may have an impact on bone formation and consolidation (Figure 5) (18-20). Ilizarov discovered that when gradual and controlled distraction is applied to the two ends of an osteotomized bone, new bone would form in the distraction gap $(1,6)$. He called this phenomenon the "Law of Tension Stress." In fact, without knowing it and long before the term mechanotransduction was coined for the first time by Harold Frost in the 1960s (21), Ilizarov laid the foundation of the whole field of mechanotransduction, where the mechanical forces of distraction applied during the process of DO are translated into molecular signals that lead to the induction of new regenerate bone (the tension 

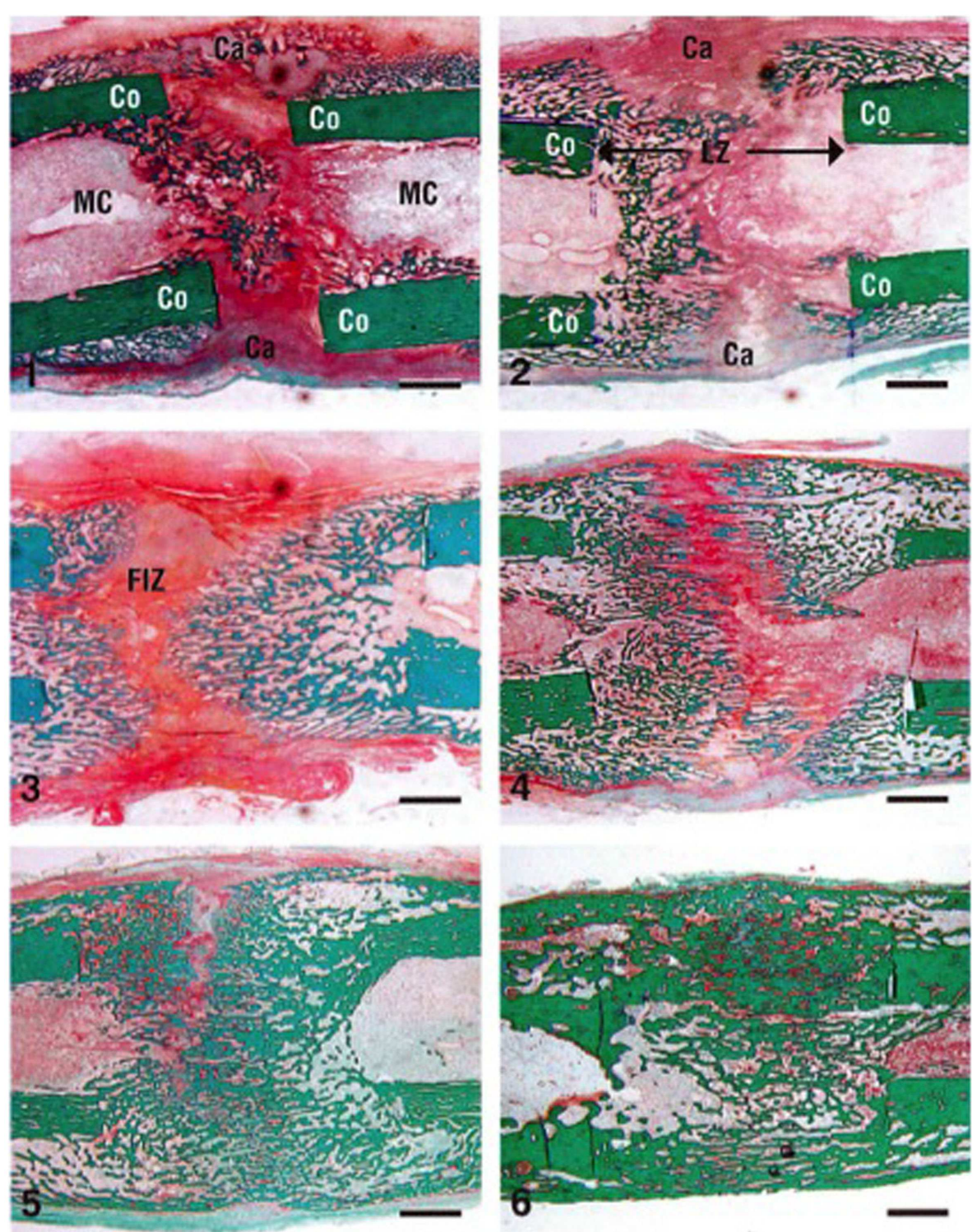

FIGURE 2 | Cellular changes in a rabbit DO model during distraction osteogenesis of the tibia (stain is Trichrome staining). The numbers indicate the number of weeks after the distraction process was started (1-3 are during the distraction phase and 4-6 are during the consolidation phase). Co, cortex; LZ, lengthened zone; Ca, callus; FIZ, fibrous interzone. Bar scale $=2 \mathrm{~mm}$. Reprinted from Rauch et al. (34), with permission from Elsevier. of the distraction forces causes stress in the distracted tissue). This controlled distraction protocol described by Ilizarov more than 60 years ago consists of a rate and rhythm of distraction of $0.25 \mathrm{~mm}$ four times a day and does not include any compression forces besides those of distraction. This unique type of mechanical loading in the context of bone regeneration, revolutionized the field of bone regeneration, and continues to be followed almost to the letter worldwide in both long bone $\operatorname{DO}(9,22)$ and mandibular DO (23).

It is surprising that in the present time and knowing the beneficial and anabolic effects of compressive forces and loading on skeletal tissue, this protocol remains largely unchallenged (2). In an attempt to accelerate bone formation in DO, several authors have analyzed the effects of applying various changes in the standard protocol by changing the rate or rhythm of distraction or by the addition of compressive forces that alternate with the distraction cycles (accordion technique). Some of these attempts - specifically, the addition of compressive forces - were successful in accelerating bone formation while others (increasing the rate of distraction) were not.

Although bone formation using standard protocol in DO has been extensively investigated at both the cellular and molecular levels, there have been very few reports analyzing the changes in the molecular expression of various proteins and molecules secondary to changes in the mechanical environment. It is the aim of this study to review the pertinent literature on that topic, 


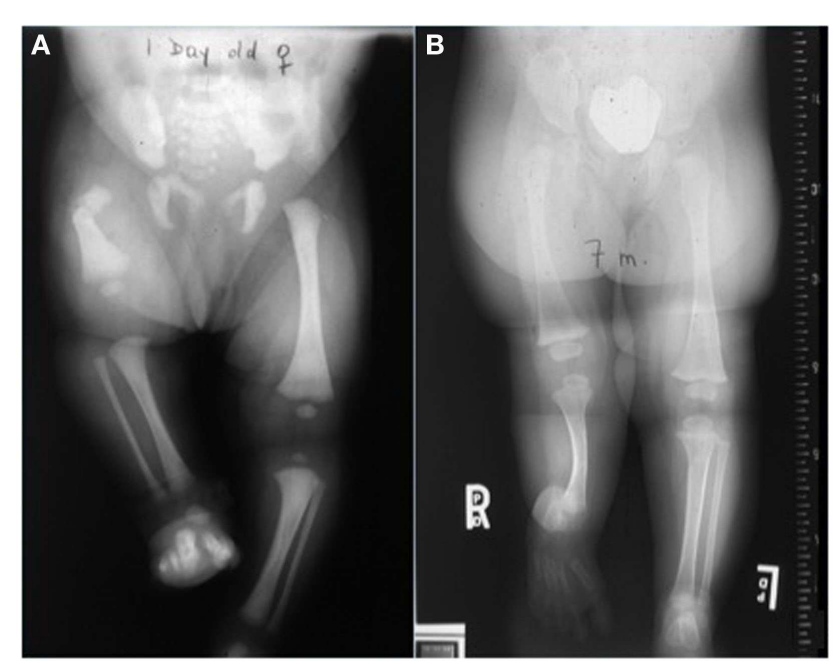

FIGURE 3 | Distraction osteogenesis is used to manage multiple orthopedic conditions including congenital short femur (A) and fibular hemimelia (B)

try to identify potential therapeutic targets for accelerating bone formation and define future research directions.

\section{MOLECULAR CHANGES DURING STANDARD DISTRACTION RATE AND RHYTHM}

The expression of various proteins and molecules and signaling pathways during the process of DO using the standard protocol $1.0 \mathrm{~mm}$ distraction a day divided into four equal increments - has been extensively investigated in both human beings and animal models of DO $(4,27,28)$. Compared to simple osteotomy without distraction, systemic up-regulation of transforming growth factor$\beta 1$ (TGF- $\beta 1$ ), platelet-derived growth factor (PDGF), insulin-like growth factor (IGF), basic fibroblast growth factor (bFGF), vascular endothelial growth factor (VEGF), and its receptors VEGFR 1 and 2 have been reported by multiple investigators suggesting that these changes are caused by the distraction process (29-31).

Using a standard DO protocol in various animal models (mice, rats, rabbits, dogs, and sheep), we and others have shown that the expression of numerous factors related to osteogenesis and chondrogenesis is mostly upregulated during the distraction phase, when the mechanical forces of distraction are applied and then, the expression of these factors is downregulated once the mechanical forces of distraction cease at the end of the distraction phase. These proteins include bone morphogenic proteins (BMPs); an extensively studied protein in the context of DO (Figure 6), in addition to TGF- $\beta 1$, FGF, IGF, and PDGF (4, 28, 32-36).

In addition, the expression of extracellular matrix proteins collagen type 1,2,4, and 10, osteocalcin, osteopontin, and osteonectin during the various phases of DO has been reported in the literature, and showed highest expression during the distraction phase of this process and decreased expression toward the end of the lengthening process $(33,37-40)$.

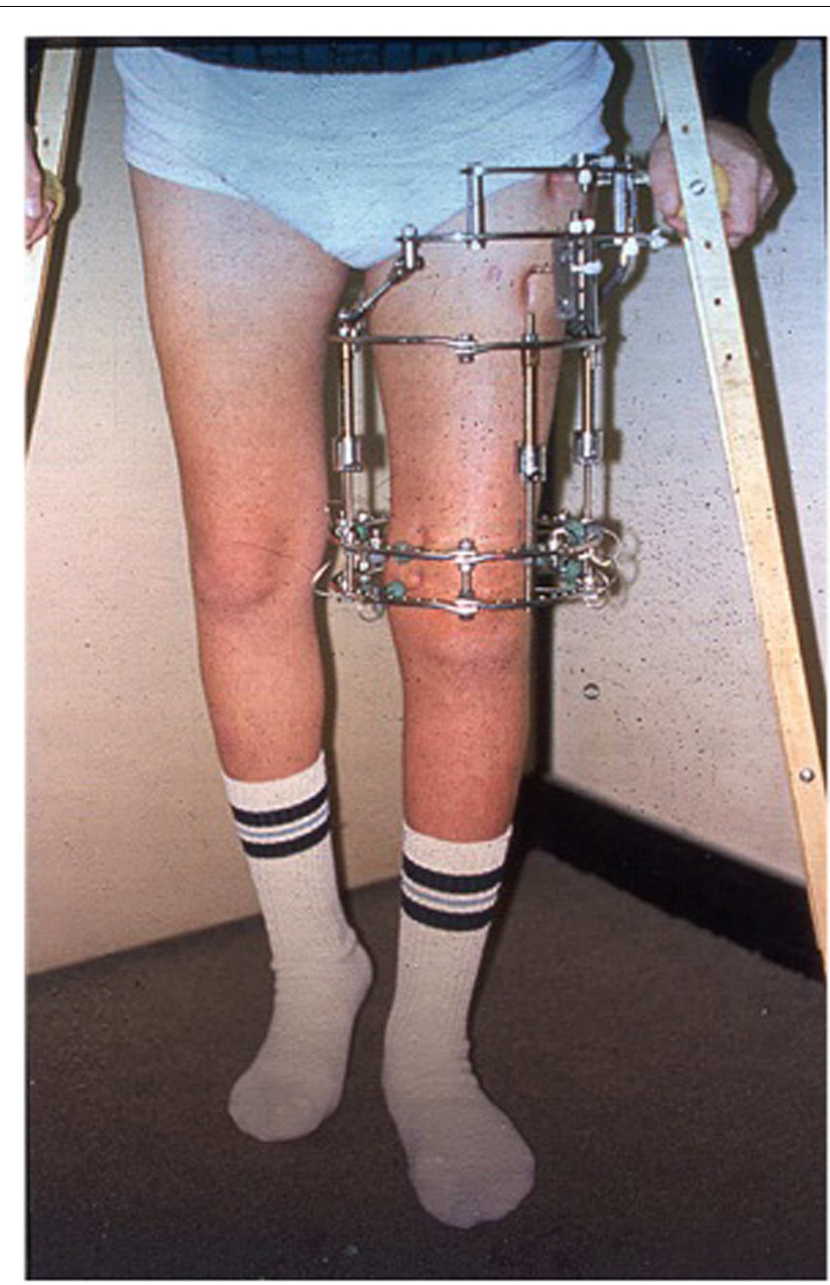

FIGURE 4 | Ilizarov ring fixator frame applied for distraction osteogenensis of the femur.

Angiogenesis and neoangiogenesis factors have also been identified in the distraction zone during DO, specifically members of the VEGF and angiopontin signaling pathways (5, 41-45).

Pro-inflammatory cytokines involved in bone repair [interleukin6 (IL-6) and tumor necrosis factor (TNF)] have been found to be expressed during the DO process, especially during the latency phase (46). The expression of bone resorption factors was investigated in the rabbit model of DO and showed diminished expression during the consolidation phase of DO $(47,48)$.

The expression of mechanotransduction factors during the distraction process has also been reported and includes extracellular signal-regulated kinase (ERK), proto-oncogene tyrosine-protein kinase Src (c-Src), integrin pathway, and focal adhesion kinase (FAK) (49-51).

\section{EFFECT OF THE MECHANICAL ENVIRONMENT IN OTHER BONE MODELS}

Although DO attracted most of the attention in the literature when assessing the effect of the mechanical environment on molecular signaling, there have been numerous studies on these effects in 


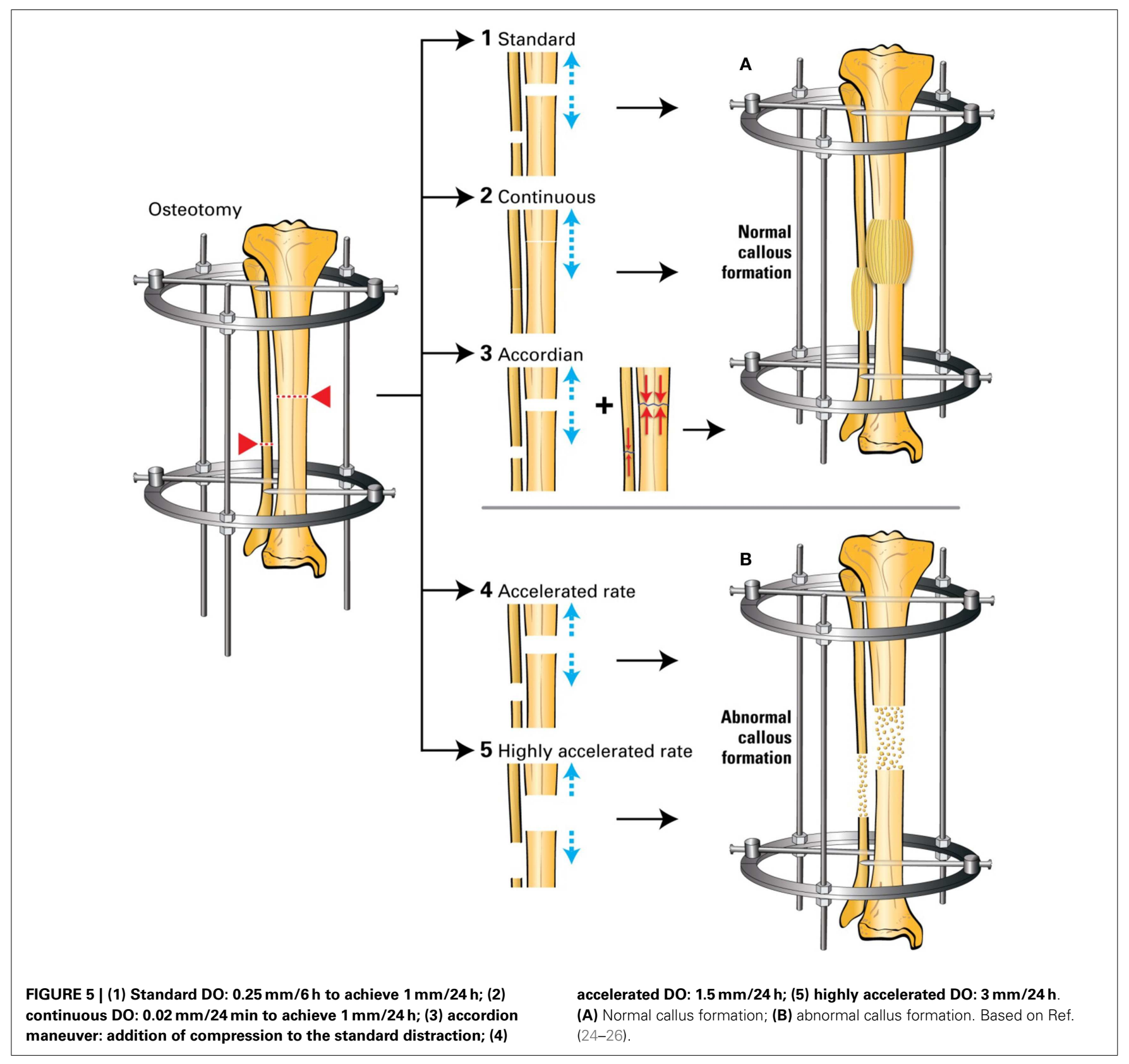

other bone models, including normal and fractured bones. The addition of mechanical loading in these models leads to an alteration of the protein and molecular signaling in the loaded segment, especially during the early loading phases (52-57). In a study by Mantila Roosa et al., they found increased bone matrix genes when loading was applied to the intact forelimb of rats compared to the contralateral unloaded limb (56). In the same study, the loaded limb also showed up-regulation of TGF- $\beta 1$, PDGF, and bFGF (56). In the same animal model, but in intact hindlimb loading, RaabCullen et al. also showed up-regulation of TGF- $\beta 1$ and IGF when a mechanical load was applied (58). These findings were further proven by multiple in vivo and in vitro studies where levels of these growth factors were found to be stimulated when loading was applied $(53,59)$. On the other hand, a downregulation of sclerostin was observed in axially loaded bones thus leading to decreased inhibition of the $\mathrm{Wnt} / \beta$-catenin signaling pathway and ultimately improving bone quality $(55,57)$.

In the fractured bones, mechanical loading also showed an agonist effect on bone formation. Palomares et al. studied these effects on protein and molecular signaling during fracture healing in their rat femoral model and found up-regulation of collagen type 2 in the loaded segment of the fracture (60). In his model, BMP 3 was also upregulated by the loading process (60). In other studies, stimulation of BMPs was observed when mechanical loading was applied, but this stimulation was mostly attributed to an indirect effect of the loading process through the $\mathrm{Wnt} / \beta$-catenin signaling 
pathway which also showed up-regulation when mechanical stimulation was applied (52-54).

\section{METHODS OF ALTERING THE MECHANICAL ENVIRONMENT}

It has been previously shown that alterations of the mechanical environment may have an effect on the healing process of DO (18-20).

Changes in the mechanical environment include addition of compression forces to the distraction forces applied, changes in the technique of distraction (acute or gradual), changes in the rate of distraction (continuous or intermittent), or changes in the rhythm of distraction (for example, accelerated distraction).

\section{ADDITION OF COMPRESSION FORCES}

In the context of DO, addition of compression forces to the distraction protocol may take one of several forms, including weight bearing on the distracted limb, alternate cycles of distraction and compression (accordion), over-lengthening, and then shortening or fixator dynamization $(18,19)$.

\section{Weight bearing}

Weight bearing during the process of DO has been shown to be an important stimulus for regenerate formation and maturation in DO (1, 6, 61, 62). Radiographical and histological evidence of significantly improved bone formation has been shown when weight bearing was applied in a goat tibial model of DO (63). In a rat model of DO, Radomisli et al. showed that in the weight bearing group BMP2/4, collagen type 1 , and osteocalcin expression was

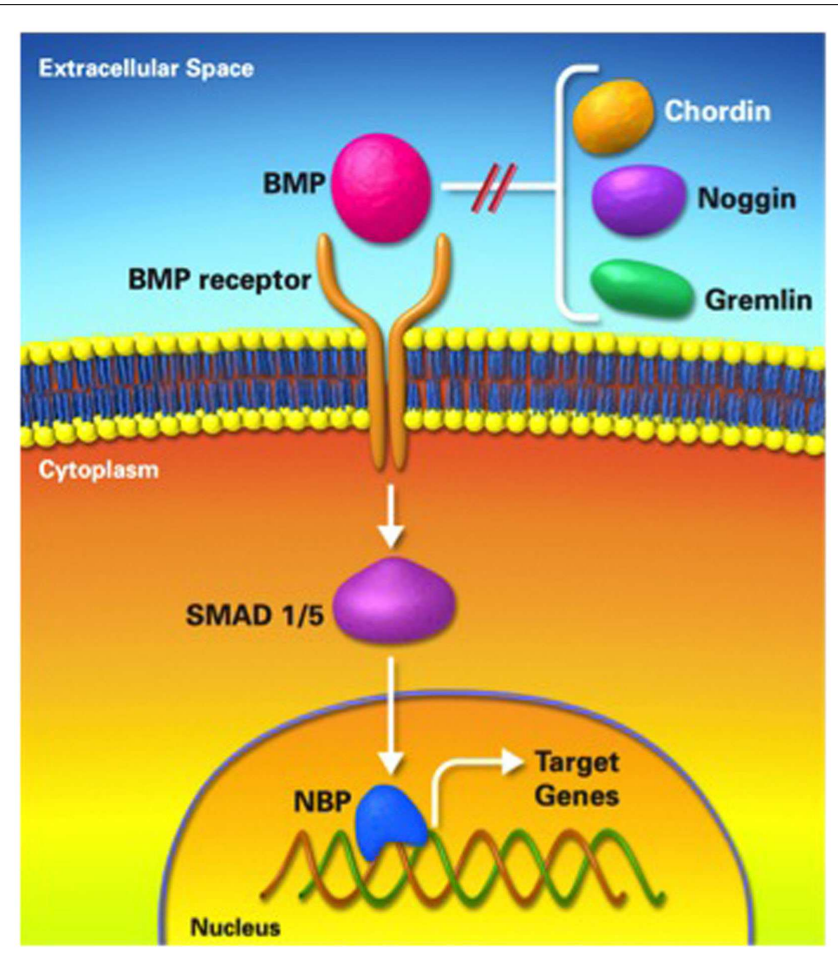

FIGURE 6 | Bone morphogenic protein pathway. BMP; bone morphogenic protein, NBP; nuclear binding protein. more abundant (64). Leung et al. also showed increased expression of TGF- $\beta 1$ when weight bearing was applied in the lengthened bone thus emphasizing the importance of early weight bearing in DO (63). Although the exact mechanism of increased weight bearing is still not fully understood, the findings in the studies of Radomisli and Leung - specifically, the increased expression of collagen type 1 , suggest that weight bearing may have a more significant effect on osteogenesis then chondrogenesis, as it is associated with early collagen type 1 and osteocalcin expression (64).

\section{Distraction with addition of compression forces}

When examining the impact of adding compression forces to the distraction protocol on molecular signaling the literature is scarce in this aspect (Table 1). In addition, there is no consensus on a standard compression-distraction protocol.

Several studies - mostly anecdotal - have shown that the addition of compressive forces alternating with the standard distraction protocol - known as the accordion technique - stimulates bone formation in the distracted gap (67-70). The accordion technique has also been successful after bone transport in obtaining union at the docking site and thus managing the bone defect $(71,72)$. It is believed that compression forces favor intramembranous bone formation, whereas distraction (tensile) forces favor endochondral bone formation (Figure 7) $(38,73-75)$. Hence, the combination of these two different types of mechanical loading may stimulate bone formation more than either type of loading alone. The literature lacks in studies examining the molecular effect of the accordion maneuver in DO, as most of the studies apply compression at the end of the distraction process and not in an alternating pattern.

Table 1 | Factor expression in distraction and compression forces in rabbit DO model.

\begin{tabular}{lll}
\hline Factor & \multicolumn{1}{c}{ Outcome } & Reference \\
\hline $\begin{array}{l}\text { BMP-4 } \\
\text { (mRNA) }\end{array}$ & $\begin{array}{l}\text { Acceleration of expression of } \\
\text { BMP-4 when compression applied }\end{array}$ & Kim et al. (65) \\
TGF- $\beta 1$ & Increased and sustained expression & Kim et al. (65) \\
(mRNA) & of TGF- $\beta$ 1 when compression & \\
& applied & \\
Osteonectin & Sustained expression of & Kim et al. (65) \\
(mRNA) & osteonectin up to 3 weeks & \\
& post-compression in the accordion & \\
& group & \\
VEGF (protein) & Increased expression of VEGF in the & Mori et al. (66) \\
& compression group &
\end{tabular}

DO, distraction osteogenesis; BMP, bone morphogenic protein; VEGF, vascular endothelial growth factor; TGF- $\beta 1$, transforming growth factor beta.

${ }^{a}$ Control group (distraction of $1 \mathrm{~mm} /$ day for 8 days) and experimental group (distraction of $1 \mathrm{~mm} /$ day for 10 days followed by a 3-day latency period after which they compressed $1 \mathrm{~mm} /$ day for 2 days) - rabbit mandibular DO.

${ }^{b}$ Control group (distraction of $0.7 \mathrm{~mm} /$ day for 14 days) and experimental group (distraction of $0.7 \mathrm{~mm} /$ day for 14 days then compression of $0.7 \mathrm{~mm} / \mathrm{day}$ for 3 days) - rabbit tibial DO. 


\section{Compression $\longrightarrow$ Endochondral ossification \\ Distraction (tensile) $\longrightarrow$ Intramembranous ossification \\ Constant compression $\longrightarrow$ Cartilage \\ Shear stress $\longrightarrow$ Fibrous tissue formation \\ FIGURE 7 | Diagram showing the process of osteogenesis by different mechanical environments. Adopted from Chao and Inoue (75).}

Another method of adding compressive forces is the protocol of over distracting the bone by a few millimeters, beyond the planned amount of lengthening followed by gradual shortening (or compression) equivalent to the amount of over-lengthening. One well-designed study by Kim et al. examined the effect of the addition of compressive forces (distraction followed by compression) on BMP-4 in the mandible DO rabbit model (65). They divided their experiment into a control group (distraction of $1 \mathrm{~mm} /$ day for 8 days) and an experimental group (distraction of $1 \mathrm{~mm} /$ day for 10 days followed by a 3-day latency period after which they compressed $1 \mathrm{~mm} /$ day for 2 days). The level of BMP-4 expression increased in both groups at the end of the distraction process, but in the experimental group the expression accelerated when compression was applied and was maintained for 2 weeks postcompression. In the same study, it was reported that the expression of TGF- $\beta 1$ not only markedly increased when compression was applied but also continued until 2 weeks after compression, whereas in the control group, there was only moderate elevation and remained elevated for a significantly shorter period of the DO process (65). Hamanishi et al. also applied this method in a rabbit model of tibia DO and found histologically increased proliferation of osteoblasts in the distraction gap (76). Surprisingly, this was associated with decreased vascularity, which they attributed to the compression forces causing vascular lumen collapse (76). Also, in a rabbit DO model, Mori et al. demonstrated that although there was collapse of the vascular lumen when compression was applied, VEGF and hypoxia inducible factor-1a (HIF-1a) showed marked increase in expression (66). They concluded that this method enhanced membranous bone formation in the distraction gap.

\section{ACUTE VERSUS GRADUAL DISTRACTION}

Compared to gradual distraction (GD), acute distraction (AD) is a less favorable method for bone regeneration in DO (Table 2) (25, $51,77)$. At the molecular level, studies comparing GD and AD in the context of DO are limited. Warren et al. found a low expression of collagen type 1 and osteocalcin in the mandibular DO rat model during the consolidation phase of the $\mathrm{AD}$ group compared with the control (25). Fang et al. compared FGF expression in GD with $\mathrm{AD}$ and found that expression of FGF increased in GD more than $\mathrm{AD}(77)$.

\section{CONTINUOUS VERSUS INTERMITTENT DISTRACTION}

Several experimental studies have shown improved bone regeneration using continuous versus intermittent DO (Table 3) (78-80). Continuous distraction leads to up-regulation of several genes
Table 2 | Factor expression in acute versus gradual distraction osteogenesis in rat mandibles.

\begin{tabular}{|c|c|c|}
\hline Factor & Outcome & Reference \\
\hline $\begin{array}{l}\text { ERK 1/2, BMP 2/4 } \\
\text { (protein) }\end{array}$ & $\begin{array}{l}\mathrm{GD} \rightarrow \uparrow \mathrm{ERK} 1 / 2+\uparrow \\
\mathrm{BMP} 2 / 4 \\
\mathrm{AD} \rightarrow \text { no ERK } 1 / 2\end{array}$ & Rhee et al. $(51)^{a}$ \\
\hline VEGF/FGF (protein) & $\begin{array}{l}\mathrm{GD} \rightarrow \uparrow \text { VEGF and FGF } \\
\mathrm{AD} \rightarrow \text { absence of GF }\end{array}$ & Fang et al. $(77)^{b}$ \\
\hline $\begin{array}{l}\text { Osteocalcin, collagen } \\
\text { type } 1 \text {, TIMP-1, VEGF } \\
\text { (mRNA) }\end{array}$ & $\begin{array}{l}\text { GD } \rightarrow \uparrow \text { osteocalcin } \\
\text { Collagen type } 1 \text { and } \\
\text { TIMP-1 compared to AD } \\
\text { Both protocols had no } \\
\text { effect on VEGF }\end{array}$ & Warren et al. (25) \\
\hline
\end{tabular}

$D O$, distraction osteogenesis; $G D$, gradual distraction; $A D$, acute distraction; ERK1/2 extracellular signal-related kinase; BMP, bone morphogenic protein; VEGF, vascular endothelial growth factor; FGF, fibroblast growth factor; GF, growth factors; TIMP-1, tissue inhibitor metalloproteinase's-1.

${ }^{a}$ Gradual distraction group (distraction of $0.6 \mathrm{~mm} /$ day for 8.5 days), Acute distraction groups (intra-operative separation of $2.1 \mathrm{~mm}$ in group 1 and $5.1 \mathrm{~mm}$ in group 2).

${ }^{b}$ Gradual distraction group (distraction of $0.5 \mathrm{~mm} /$ day for 8 days) and acute distraction group (intra-operative separation of $4 \mathrm{~mm}$ ).

c Gradual distraction group (distraction of $0.5 \mathrm{~mm} /$ day for 6 days) and acute distraction group (intra-operative separation of $3 \mathrm{~mm}$ ).

more than intermittent traction $(78,79,81)$. In a mandibular DO rabbit model comparing continuous versus intermittent distraction, Zheng et al. found that VEGF was significantly upregulated at the early stage of distraction phase and remained elevated throughout the consolidation phase, while FGF was significantly higher at the early stage of distraction phase only and no significant difference was established between the two groups in the other stages. Also, there was advanced bone formation and partial bone healing in continuous DO based on histological examination (78). In the same model, Zheng et al. also reported that, compared to intermittent DO, the mRNA level for BMP-2 in rabbits undergoing continuous distraction, was significantly higher throughout the distraction phase, whereas no significant difference was noted in the consolidation phase (79). Furthermore, the mRNA expression of TGF- $\beta 1$ was significantly higher at the early stage of distraction phase in the continuous distraction group, although no significant difference was found between two groups in other stages (79).

Contradicting the previously mentioned positive results of continuous distraction, a recent clinical study by Bright et al. showed no significant difference between intermittent $(0.25 \mathrm{~mm}$ 4 times/day) and continuous distraction (1/1440 mm 1400 times/day) in time to union or complication rate (82).

\section{VARIABLE DISTRACTION RATE AND RHYTHM}

The effect of the rate and rhythm used in the applied DO protocol has a significant effect on the expression of factors involved in the DO process (Table 4). Cheung et al. examined the expression of BMP-2, -4 , and -7 with routine $(0.9 \mathrm{~mm} /$ day $)$ and rapid $(2.7 \mathrm{~mm} /$ day $)$ distraction in the mandible DO rabbit model (83). 
They showed that in the early consolidation phase there was intense signaling of BMP-2 and BMP-4 at the edges of the distraction regenerate in the routine group, which spread to the primary trabecule as the consolidation phase progressed, whereas in the rapid group there were only weak signals of these BMPs in the area of the distraction regenerate and no extension to other parts of the bone throughout the consolidation phase. In both groups, BMP-7 was not detected throughout the experimental periods.

Schiller et al. studied the alteration of expression of various growth factors in rapid distraction $(0.75 \mathrm{~mm}$ twice/day) compared to routine $(0.25 \mathrm{~mm}$ twice/day). They found that there was decreased cellular staining of FGF, VEGF, and PDGF in the rapid distraction group starting on the first day of lengthening (26).

Table 3 | Factor expression in continuous versus intermittent distraction osteogenesis in rabbit mandibles.

\begin{tabular}{lll}
\hline Factor & Outcome & Reference \\
\hline TIMP-1 & Up-regulating TIMP-1 in continuous & $\begin{array}{l}\text { Liu et al. } \\
(80,81)^{a}\end{array}$ \\
T(mRNA) & DO & Zheng et al. \\
TGF- $\beta$ 1/BMP 2 & High level of TGF- $\beta$ 1 and BMP 2 in & $(78,79)^{a}$ \\
VEGF/bFGF & continuous DO & Zheng et al. \\
$(m R N A)$ & environment for angiogenesis & $(78,79)^{a}$ \\
& through up-regulation of the & \\
& angiogenic mediators &
\end{tabular}

DO, distraction osteogenesis; TIMP-1, tissue inhibitor metalloproteinase's-1; $B M P$, bone morphogenic protein; TGF- $\beta$ 1, transforming growth factor beta; $b F G F$, basic fibroblast growth factor; VEGF, vascular endothelial growth factor.

${ }^{a}$ Continuous distraction group $10.9 \mathrm{~mm} /$ day for 11 days at a rate of 8 times/s) and intermittent distraction group $(0.9 \mathrm{~mm} /$ day for 11 days at a rate of once per day).

\section{DISCUSSION}

The beneficial effects of mechanical loading on bone formation have been known for more than a century, when Wolff developed the concept that bone adapts to its environment (75). However, of all the forms of mechanical loading - compression, tension (or distraction), bending, torsion, and shear - only compression forces were mostly recognized as having an anabolic effect on bone formation. It was Ilizarov, in the 1950s, who was the first one to introduce the concept that distraction (tension) forces could also lead to bone formation, provided these forces are applied in a controlled environment, and that was the key to the success of the technique of DO $(1,6)$. As previously mentioned, although DO is a very successful technique in generating large amounts of new bone, the long period of time the external fixator has to be kept on until the newly formed bone consolidates, presented a major problem of this technique. The question then arises: how to accelerate newly formed bone in the distracted gap? Numerous techniques have been described to accelerate bone formation, however, manipulation of the mechanical loading environment is probably the most attractive as it is non-invasive, easily applicable, and furthermore adds no cost to the technique. This led some authors to challenge the standard distraction protocol developed by Ilizarov. Several reports in the literature have shown that the addition of compressive forces to the distraction protocol, specifically the accordion technique, could be beneficial in accelerating bone formation in the distracted gap $(67-70,84)$. However, there has been no detailed analysis of this technique: how much compression should be applied, which phase of DO should the compression be added and for how long? More importantly, it still remains largely unknown how the effects of compression forces differ from those of distraction forces at the molecular level in stimulating bone formation in the context of DO.

The expression of multiple growth factors has been identified in context of standard DO protocol, including TGF- $\beta$, PDGF, IGF, bFGF, and VEGF. While alteration of the mechanical environment

Table 4 | Factor expression in variable distraction rates and rhythms of distraction osteogenesis.

\begin{tabular}{|c|c|c|c|c|}
\hline Factor & Distraction protocol & Model & Outcome & Reference \\
\hline $\begin{array}{l}\text { BMP-2/4/7 } \\
\text { (protein) }\end{array}$ & $0.9 \mathrm{~mm} /$ day versus $2.7 \mathrm{~mm} /$ day & $\begin{array}{l}\text { Mandibular DO in } \\
\text { rabbits }\end{array}$ & $\begin{array}{l}\text { Increased Expression of BMP-2/4 in } \\
0.9 \mathrm{~mm} / \text { day group } \\
\text { No BMP-7 in both groups }\end{array}$ & Cheung et al. (83) \\
\hline $\begin{array}{l}\text { FGFNEGF/PDGF } \\
\text { (protein) }\end{array}$ & $0.5 \mathrm{~mm} /$ day versus $1.5 \mathrm{~mm} /$ day & Femur DO in rats & $\begin{array}{l}\text { Increased expression of VEGF, FGF and } \\
\text { PDGF in } 0.5 \mathrm{~mm} / \text { day group }\end{array}$ & Schiller et al. (26) \\
\hline $\begin{array}{l}\text { Endothelial cells } \\
\text { antigen (protein) }\end{array}$ & $\begin{array}{l}\text { Four varying rates }(0.3,0.7,1.3, \\
\text { and } 2.7 \mathrm{~mm} / \text { day })\end{array}$ & Tibia DO in rabbits & $\begin{array}{l}\text { The vascularization process was } \\
\text { maximally stimulated at distraction rates } \\
\text { of } 0.7 \text { and } 1.3 \mathrm{~mm} / \text { day. While impaired in } \\
0.3 \mathrm{~mm} / \text { day and not maximally stimulated } \\
\text { in } 2.7 \mathrm{~mm} / \text { day }\end{array}$ & Li et al. $(24,38)$ \\
\hline $\begin{array}{l}\text { Collagen type } 4 \\
\text { (protein) }\end{array}$ & $\begin{array}{l}\text { Four varying rates }(0.3,0.7,1.3 \text {, } \\
\text { and } 2.7 \mathrm{~mm} / \text { day })\end{array}$ & Tibia DO in rabbits & $\begin{array}{l}\text { Collagen type } 4 \text { expression was highest at } \\
\text { rates of } 0.7 \mathrm{~mm} / \text { day and } 1.3 \mathrm{~mm} / \text { day }\end{array}$ & Li et al. $(24,38)$ \\
\hline
\end{tabular}

DO, distraction osteogenesis; BMP, bone morphogenic protein; VEGF, vascular endothelial growth factor; FGF, fibroblast growth factor; PDGF, platelet-derived growth factor. 
lead to variable changes in expression of these factors. Except for the BMP pathway, we were unable to identify any other specific protein, molecule or pathway that clearly characterizes specific changes in signaling when the biomechanical loading environment is altered. The BMP pathway has been extensively studied in the context of bone regeneration and DO and we and others have shown that it plays a significant role in DO using the standard protocol $(28,32,36,85)$. We have also shown (Tables 1-4) that the expression of BMPs changes when the mechanical loading environment is altered, specifically an increased expression of BMPs when compression forces are added to the standard protocol and when continuous distraction is applied. More research needs to be done in that area to identify which specific combination of biomechanical forces leads to optimal expression of BMPs.

Another possible explanation on the beneficial effects of compression loading on bone formation in DO at the molecular level is related to the expression of sclerostin and the difference in sclerostin inhibition with various types of loading. The emergence of the Wnt pathway as a major player in bone regeneration, along with its alteration when sclerostin is inhibited led to extensive research in that area $(86,87)$. We know today that sclerostin inhibition is one of the numerous pathways through which mechantransduction may lead to new bone formation $(55,88)$. In our laboratory, we have demonstrated in a mouse model of DO that various members of the Wnt signaling pathway are expressed during the distraction process (86) and that systemic application of sclerostin antibodies caused increased bone formation in the distracted gap (87). However, to the best of our knowledge, there has been no study evaluating the effects of altering the mechanical loading environment in the context of DO on the expression of Wnt pathway members and the degree of sclerostin inhibition. The only study we were able to find comparing the effects of compression versus distraction on the expression of sclerostin, was by Robling et al., who showed in an ulnar loading model in the rat that compression loading causes $80 \%$ suppression of sclerostin, while distraction loading caused only $20 \%$ inhibition of sclerostin (55). This is an extremely important observation as it supports the hypothesis that the addition of compressive loading to the distraction protocol may be beneficial to bone formation by suppressing more sclerostin than distraction forces only. We believe that future research should also focus on analyzing the effects of altering the biomechanical loading environment on the expression of various members of this pathway and hence try to identify the optimal "non-invasive tissue engineering" method to enhance bone formation in DO.

\section{ACKNOWLEDGMENTS}

The authors would like to thank Dr. Sebastian Rendon, orthopedic researcher at Shriners Hospital for children for his valuable contribution in literature review. Also, we would like to thank Guylaine Bédard graphic artist and photographer in Shriners Hospital for children for her participation in image and pictures design.

\section{REFERENCES}

1. Ilizarov GA. The tension-stress effect on the genesis and growth of tissues: part II. The influence of the rate and frequency of distraction. Clin Orthop Relat Res (1989) 239:263-85.

2. Ilizarov GA. Clinical application of the tension-stress effect for limb lengthening. Clin Orthop Relat Res (1990) 250:8-26.
3. Green SA. The Ilizarov method of distraction osteogenesis. In: Hamdy RC, McCarthy J, editors. Management of Limb Length Discrepancy. Rosemont, IL: American Academy of Orthopaedic Surgeons (2011). p. 39-44.

4. Al-Aql ZS, Alagl AS, Graves DT, Gerstenfeld LC, Einhorn TA. Molecular mechanisms controlling bone formation during fracture healing and distraction osteogenesis. J Dent Res (2008) 87:107-18. doi:10.1177/154405910808700215

5. Choi IH, Chung CY, Cho TJ, Yoo WJ. Angiogenesis and mineralization during distraction osteogenesis. J Korean Med Sci (2002) 17:435-47. doi:10.3346/jkms. 2002.17.4.435

6. Ilizarov GA. The tension-stress effect on the genesis and growth of tissues. Part I. The influence of stability of fixation and soft-tissue preservation. Clin Orthop Relat Res (1989) 238:249-81.

7. Hamdy RC, Rendon JS, Tabrizian M. Distraction osteogenesis and its challenges in bone regeneration. In: Tal $\mathrm{H}$, editor. Bone Regeneration. InTech (2012):185-212. doi:10.5772/32229. Available from: http://www.intechopen. com/books/bone-regeneration/distraction-osteogenesis-and-its-challenges-inbone-regeneration

8. Codivilla A. The classic: on the means of lengthening, in the lower limbs, the muscles and tissues which are shortened through deformity. 1905. Clin Orthop Relat Res (2008) 466:2903-9. doi:10.1007/s11999-008-0518-7

9. Birch JG, Samchukov ML. Use of the Ilizarov method to correct lower limb deformities in children and adolescents. J Am Acad Orthop Surg (2004) 12:144-54.

10. McCarthy JG, Schreiber J, Karp N, Thorne CH, Grayson BH. Lengthening the human mandible by gradual distraction. Plast Reconstr Surg (1992) 89:1-8. doi:10.1097/00006534-199201000-00001

11. Margaride LA, Breuer J. Transmaxillary osteogenic distraction with intraoral tooth-borne distractors. J Craniofac Surg (2012) 23:1425-7. doi:10.1097/SCS. 0b013e31824ef7b4

12. Ohba S, Tobita T, Tajima N, Matsuo K, Yoshida N, Asahina I. Correction of an asymmetric maxillary dental arch by alveolar bone distraction osteogenesis. Am J Orthod Dentofacial Orthop (2013) 143:266-73. doi:10.1016/j.ajodo. 2011.09.013

13. Uribe F, Agarwal S, Janakiraman N, Shafer D, Nanda R. Bidimensional dentoalveolar distraction osteogenesis for treatment efficiency. Am J Orthod Dentofacial Orthop (2013) 144:290-8. doi:10.1016/j.ajodo.2012.09.023

14. Paley D. Problems, obstacles, and complications of limb lengthening by the Ilizarov technique. Clin Orthop Relat Res (1990) 250:81-104.

15. Garcia-Cimbrelo E, Olsen B, Ruiz-Yague M, Fernandez-Baillo N, MunueraMartinez L. Ilizarov technique. Results and difficulties. Clin Orthop Relat Res (1992) 283:116-23.

16. Sabharwal S. Enhancement of bone formation during distraction osteogenesis: pediatric applications. J Am Acad Orthop Surg (2011) 19:101-11.

17. Makhdom AM, Hamdy RC. The role of growth factors on acceleration of bone regeneration during distraction osteogenesis. Tissue Eng Part B Rev (2013) 19:442-53. doi:10.1089/ten.TEB.2012.0717

18. Aronson J, Harp JH. Mechanical forces as predictors of healing during tibial lengthening by distraction osteogenesis. Clin Orthop Relat Res (1994) 301:73-9.

19. Waanders NA, Richards M, Steen H, Kuhn JL, Goldstein SA, Goulet JA. Evaluation of the mechanical environment during distraction osteogenesis. Clin Orthop Relat Res (1998) 349:225-34. doi:10.1097/00003086-199804000-00028

20. Saunders MM, Lee JS. The influence of mechanical environment on bone healing and distraction osteogenesis. Atlas Oral Maxillofac Surg Clin North Am (2008) 16:147-58. doi:10.1016/j.cxom.2008.04.006

21. Frost HM. The Utah Paradigm of Skeletal Physiology Vol. 1-2. ISMNI (1960).

22. Li G, Simpson AH, Kenwright J, Triffitt JT. Assessment of cell proliferation in regenerating bone during distraction osteogenesis at different distraction rates. J Orthop Res (1997) 15:765-72. doi:10.1002/jor.1100150520

23. Mofid MM, Manson PN, Robertson BC, Tufaro AP, Elias JJ, Vander Kolk CA. Craniofacial distraction osteogenesis: a review of 3278 cases. Plast Reconstr Surg (2001) 108:1103-14. doi:10.1097/00006534-200110000-00001

24. Li G, Simpson AH, Kenwright J, Triffitt JT. Effect of lengthening rate on angiogenesis during distraction osteogenesis. J Orthop Res (1999) 17:362-7. doi:10.1002/jor.1100170310

25. Warren SM, Mehrara BJ, Steinbrech DS, Paccione MF, Greenwald JA, Spector JA, et al. Rat mandibular distraction osteogenesis: part III. Gradual distraction versus acute lengthening. Plast Reconstr Surg (2001) 107:441-53. doi:10.1097/00006534-200102000-00021

26. Schiller JR, Moore DC, Ehrlich MG. Increased lengthening rate decreases expression of fibroblast growth factor 2, platelet-derived growth factor, vascular 
endothelial growth factor, and CD31 in a rat model of distraction osteogenesis. J Pediatr Orthop (2007) 27:961-8. doi:10.1097/BPO.0b013e3181558c37

27. Bouletreau PJ, Warren SM, Longaker MT. The molecular biology of distraction osteogenesis. J Craniomaxillofac Surg (2002) 30:1-11. doi:10.1054/jcms.2001. 0263

28. Haque T, Hamade F, Alam N, Kotsiopriftis M, Lauzier D, St-Arnaud R, et al. Characterizing the BMP pathway in a wild type mouse model of distraction osteogenesis. Bone (2008) 42:1144-53. doi:10.1016/j.bone.2008.01.028

29. Holbein O, Neidlinger-Wilke C, Suger G, Kinzl L, Claes L. Ilizarov callus distraction produces systemic bone cell mitogens. J Orthop Res (1995) 13:629-38. doi:10.1002/jor.1100130420

30. Lammens J, Liu Z, Aerssens J, Dequeker J, Fabry G. Distraction bone healing versus osteotomy healing: a comparative biochemical analysis. J Bone Miner Res (1998) 13:279-86. doi:10.1359/jbmr.1998.13.2.279

31. Weiss S, Baumgart R, Jochum M, Strasburger CJ, Bidlingmaier M. Systemic regulation of distraction osteogenesis: a cascade of biochemical factors. J Bone Miner Res (2002) 17:1280-9. doi:10.1359/jbmr.2002.17.7.1280

32. Li G, Berven S, Simpson H, Triffitt JT. Expression of BMP-4 mRNA during distraction osteogenesis in rabbits. Acta Orthop Scand (1998) 69:420-5. doi: 10.3109/17453679808999060

33. Sato M, Yasui N, Nakase T, Kawahata H, Sugimoto M, Hirota S, et al. Expression of bone matrix proteins mRNA during distraction osteogenesis. J Bone Miner Res (1998) 13:1221-31. doi:10.1359/jbmr.1998.13.8.1221

34. Rauch F, Lauzier D, Croteau S, Travers R, Glorieux FH, Hamdy R. Temporal and spatial expression of bone morphogenetic protein-2, -4 , and -7 during distraction osteogenesis in rabbits. Bone (2000) 27:453-9. doi:10.1016/S8756-3282(00) 00337-9

35. Haque T, Amako M, Nakada S, Lauzier D, Hamdy RC. An immunohistochemical analysis of the temporal and spatial expression of growth factors FGF 1,2 and 18, IGF 1 and 2, and TGFbetal during distraction osteogenesis. Histol Histopathol (2007) 22:119-28.

36. Alam N, St-Arnaud R, Lauzier D, Rosen V, Hamdy RC. Are endogenous BMPs necessary for bone healing during distraction osteogenesis? Clin Orthop Relat Res (2009) 467:3190-8. doi:10.1007/s11999-009-1065-6

37. Tajana GF, Morandi M, Zembo MM. The structure and development of osteogenetic repair tissue according to Ilizarov technique in man. Characterization of extracellular matrix. Orthopedics (1989) 12:515-23.

38. Li G, Simpson AH, Triffitt JT. The role of chondrocytes in intramembranous and endochondral ossification during distraction osteogenesis in the rabbit. Calcif Tissue Int (1999) 64:310-7. doi:10.1007/s002239900625

39. Knabe C, Nicklin S, Yu Y, Walsh WR, Radlanski RJ, Marks C, et al. Growth factor expression following clinical mandibular distraction osteogenesis in humans and its comparison with existing animal studies. J Craniomaxillofac Surg (2005) 33:361-9. doi:10.1016/j.jcms.2005.07.003

40. Feng X, Tuo X, Chen F, Wu W, Ding Y, Duan Y, et al. Ultrastructural cell response to tension stress during mandibular distraction osteogenesis. Br J Oral Maxillofac Surg (2008) 46:527-32. doi:10.1016/j.bjoms.2008.03.005

41. Pacicca DM, Patel N, Lee C, Salisbury K, Lehmann W, Carvalho R, et al. Expression of angiogenic factors during distraction osteogenesis. Bone (2003) 33:889-98. doi:10.1016/j.bone.2003.06.002

42. Sojo K, Sawaki Y, Hattori H, Mizutani H, Ueda M. Immunohistochemical study of vascular endothelial growth factor (VEGF) and bone morphogenetic protein2, -4 (BMP-2, -4) on lengthened rat femurs. J Craniomaxillofac Surg (2005) 33:238-45. doi:10.1016/j.jcms.2005.02.004

43. Byun JH, Park BW, Kim JR, Lee JH. Expression of vascular endothelial growth factor and its receptors after mandibular distraction osteogenesis. Int J Oral Maxillofac Surg (2007) 36:338-44. doi:10.1016/j.ijom.2006.10.013

44. Jacobsen KA, Al-Aql ZS, Wan C, Fitch JL, Stapleton SN, Mason ZD, et al. Bone formation during distraction osteogenesis is dependent on both VEGFR1 and VEGFR2 signaling. J Bone Miner Res (2008) 23:596-609. doi:10.1359/jbmr. 080103

45. Mandu-Hrit M, Seifert E, Kotsiopriftis M, Lauzier D, Haque T, Rohlicek C, et al. OP-1 injection increases VEGF expression but not angiogenesis in a rabbit model of distraction osteogenesis. Growth Factors (2008) 26:143-51. doi:10.1080/08977190802106154

46. Cho TJ, Kim JA, Chung CY, Yoo WJ, Gerstenfeld LC, Einhorn TA, et al. Expression and role of interleukin-6 in distraction osteogenesis. Calcif Tissue Int (2007) 80:192-200. doi:10.1007/s00223-006-0240-y
47. Wang LC, Takahashi I, Sasano Y, Sugawara J, Mitani H. Osteoclastogenic activity during mandibular distraction osteogenesis. J Dent Res (2005) 84:1010-5. doi:10.1177/154405910508401108

48. Ge WL, Xie ZJ, He JF. Expression of c-fos, OPG, OPGL in rabbit mandibular distraction osteogenesis zone. Zhejiang Da Xиe Xue Bao Yi Xue Ban (2006) 35:496-500.

49. Tong L, Buchman SR, Ignelzi MA Jr, Rhee S, Goldstein SA. Focal adhesion kinase expression during mandibular distraction osteogenesis: evidence for mechanotransduction. Plast Reconstr Surg (2003) 111:211-22. doi:10.1097/00006534200301000-00037

50. Rhee ST, Buchman SR. Colocalization of c-Src (pp60src) and bone morphogenetic protein $2 / 4$ expression during mandibular distraction osteogenesis: in vivo evidence of their role within an integrin-mediated mechanotransduction pathway. Ann Plast Surg (2005) 55:207-15. doi:10.1097/01.sap.0000164576. 10754.aa

51. Rhee ST, El-Bassiony L, Buchman SR. Extracellular signal-related kinase and bone morphogenetic protein expression during distraction osteogenesis of the mandible: in vivo evidence of a mechanotransduction mechanism for differentiation and osteogenesis by mesenchymal precursor cells. Plast Reconstr Surg (2006) 117:2243-9. doi:10.1097/01.prs.0000224298.93486.1b

52. Hens JR, Wilson KM, Dann P, Chen X, Horowitz MC, Wysolmerski JJ. TOPGAL mice show that the canonical Wnt signaling pathway is active during bone development and growth and is activated by mechanical loading in vitro. $J$ Bone Miner Res (2005) 20:1103-13. doi:10.1359/JBMR.050210

53. Lau KH, Kapur S, Kesavan C, Baylink DJ. Up-regulation of the Wnt, estrogen receptor, insulin-like growth factor-I, and bone morphogenetic protein pathways in $\mathrm{C} 57 \mathrm{BL} / 6 \mathrm{~J}$ osteoblasts as opposed to $\mathrm{C} 3 \mathrm{H} / \mathrm{HeJ}$ osteoblasts in part contributes to the differential anabolic response to fluid shear. J Biol Chem (2006) 281:9576-88. doi:10.1074/jbc.M509205200

54. Robinson JA, Chatterjee-Kishore M, Yaworsky PJ, Cullen DM, Zhao W, Li C, et al. Wnt/beta-catenin signaling is a normal physiological response to mechanical loading in bone. J Biol Chem (2006) 281:31720-8. doi:10.1074/jbc.M602308200

55. Robling AG, Niziolek PJ, Baldridge LA, Condon KW, Allen MR, Alam I, et al. Mechanical stimulation of bone in vivo reduces osteocyte expression of Sost/sclerostin. J Biol Chem (2008) 283:5866-75. doi:10.1074/jbc.M705092200

56. Mantila Roosa SM, Liu Y, Turner CH. Gene expression patterns in bone following mechanical loading. J Bone Miner Res (2011) 26:100-12. doi:10.1002/jbmr.193

57. Moustafa A, Sugiyama T, Prasad J, Zaman G, Gross TS, Lanyon LE, et al. Mechanical loading-related changes in osteocyte sclerostin expression in mice are more closely associated with the subsequent osteogenic response than the peak strains engendered. Osteoporos Int (2012) 23:1225-34. doi:10.1007/s00198-011-1656-4

58. Raab-Cullen DM, Thiede MA, Petersen DN, Kimmel DB, Recker RR. Mechanical loading stimulates rapid changes in periosteal gene expression. Calcif Tissue Int (1994) 55:473-8. doi:10.1007/BF00298562

59. Lean JM, Jagger CJ, Chambers TJ, Chow JW. Increased insulin-like growth factor I mRNA expression in rat osteocytes in response to mechanical stimulation. Am J Physiol (1995) 268:E318-27.

60. Palomares KT, Gleason RE, Mason ZD, Cullinane DM, Einhorn TA, Gerstenfeld LC, et al. Mechanical stimulation alters tissue differentiation and molecular expression during bone healing. J Orthop Res (2009) 27:1123-32. doi:10.1002/jor.20863

61. Green SA. Postoperative management during limb lengthening. Orthop Clin North Am (1991) 22:723-34.

62. Fink B, Krieger M, Schneider T, Menkhaus S, Fischer J, Ruther W. Factors affecting bone regeneration in Ilizarov callus distraction. Unfallchirurg (1995) 98:633-9.

63. Leung KS, Cheung WH, Yeung HY, Lee KM, Fung KP. Effect of weightbearing on bone formation during distraction osteogenesis. Clin Orthop Relat Res (2004) 419:251-7. doi:10.1097/00003086-200402000-00041

64. Radomisli TE, Moore DC, Barrach HJ, Keeping HS, Ehrlich MG. Weight-bearing alters the expression of collagen types I and II, BMP $2 / 4$ and osteocalcin in the early stages of distraction osteogenesis. J Orthop Res (2001) 19:1049-56. doi:10.1016/S0736-0266(01)00044-4

65. Kim UK, Park SJ, Seong WJ, Heo J, Hwang DS, Kim YD, et al. Expression of TGF-betal, osteonectin, and BMP-4 in mandibular distraction osteogenesis with compression stimulation: reverse transcriptase-polymerase chain reaction study and biomechanical test. J Oral Maxillofac Surg (2010) 68:2076-84. doi:10.1016/j.joms.2009.09.070 
66. Mori S, Akagi M, Kikuyama A, Yasuda Y, Hamanishi C. Axial shortening during distraction osteogenesis leads to enhanced bone formation in a rabbit model through the HIF-1alpha/vascular endothelial growth factor system. J Orthop Res (2006) 24:653-63. doi:10.1002/jor.20076

67. Perren SM, Huggler A, Russenberger M, Allgower M, Mathys R, Schenk R, et al. The reaction of cortical bone to compression. Acta Orthop Scand Suppl (1969) 125:19-29.

68. Krishnan A, Pamecha C, Patwa JJ. Modified Ilizarov technique for infected nonunion of the femur: the principle of distraction-compression osteogenesis. J Orthop Surg (Hong Kong) (2006) 14:265-72.

69. Claes L, Augat P, Schorlemmer S, Konrads C, Ignatius A, Ehrnthaller C. Temporary distraction and compression of a diaphyseal osteotomy accelerates bone healing. J Orthop Res (2008) 26:772-7. doi:10.1002/jor.20588

70. Ozgul S, Akdeniz ZD, Celebiler O, Alcan T, Sav A. The effect of 2 different distraction-compression models on new bone generation. J Oral Maxillofac Surg (2012) 70:e490-9. doi:10.1016/j.joms.2012.05.022

71. Tsuchiya H, Tomita K, Minematsu K, Mori Y, Asada N, Kitano S. Limb salvage using distraction osteogenesis. A classification of the technique. J Bone Joint Surg $\mathrm{Br}$ (1997) 79:403-11. doi:10.1302/0301-620X.79B3.7198

72. Iacobellis C, Berizzi A, Aldegheri R. Bone transport using the Ilizarov method: a review of complications in 100 consecutive cases. Strategies Trauma Limb Reconstr (2010) 5:17-22. doi:10.1007/s11751-010-0085-9

73. Hamdy RC, Silvestri A, Rivard CH, Ehrlich M. Histologic evaluation of bone regeneration in cases of limb lengthening by Ilizarov's technique. An experimental study in the dog. Ann Chir (1997) 51:875-83.

74. Yasui N, Sato M, Ochi T, Kimura T, Kawahata H, Kitamura Y, et al. Three modes of ossification during distraction osteogenesis in the rat. J Bone Joint Surg Br (1997) 79:824-30. doi:10.1302/0301-620X.79B5.7423

75. Chao EY, Inoue N. Biophysical stimulation of bone fracture repair, regeneration and remodelling. Eur Cell Mater (2003) 6:72-84.

76. Hamanishi C, Yoshii T, Totani Y, Tanaka S. Lengthened callus activated by axial shortening. Histological and cytomorphometrical analysis. Clin Orthop Relat Res (1994) 307:250-4.

77. Fang TD, Salim A, Xia W, Nacamuli RP, Guccione S, Song HM, et al. Angiogenesis is required for successful bone induction during distraction osteogenesis. J Bone Miner Res (2005) 20:1114-24. doi:10.1359/jbmr.050301

78. Zheng LW, Ma L, Cheung LK. Angiogenesis is enhanced by continuous traction in rabbit mandibular distraction osteogenesis. J Craniomaxillofac Surg (2009) 37:405-11. doi:10.1016/j.jcms.2009.03.007

79. Zheng LW, Ma L, Cheung LK. Comparison of gene expression of osteogenic factors between continuous and intermittent distraction osteogenesis in rabbit mandibular lengthening. Oral Surg Oral Med Oral Pathol Oral Radiol Endod (2009) 108:496-9. doi:10.1016/j.tripleo.2009.05.038

80. Liu XL, Zhang HX, Ma L, Peng L, Cheung LK, Zheng LW. Responses of distraction regenerate to high-frequency traction at a rapid rate. J Trauma Acute Care Surg (2012) 72:1035-9. doi:10.1097/TA.0b013e31823cc867
81. Liu XL, Cheung LK, Zhang HX, Li JY, Ma L, Zheng LW. Comparison of gene expression of tissue inhibitor of matrix metalloproteinase- 1 between continuous and intermittent distraction osteogenesis: a quantitative study on rabbits. JCraniomaxillofac Surg (2012) 40:e185-8. doi:10.1016/j.jcms.2011.10.005

82. Bright AS, Herzenberg JE, Paley D, Weiner I, Burghardt RD. Preliminary experience with motorized distraction for tibial lengthening. Strategies Trauma Limb Reconstr (2014) 9(2):97-100. doi:10.1007/s11751-014-0191-1

83. Cheung LK, Zheng LW, Ma L. Effect of distraction rates on expression of bone morphogenetic proteins in rabbit mandibular distraction osteogenesis. J Craniomaxillofac Surg (2006) 34:263-9. doi:10.1016/j.jcms.2006.02.004

84. Kim UK, Chung IK, Lee KH, Swift JQ, Seong WJ, Ko CC. Bone regeneration in mandibular distraction osteogenesis combined with compression stimulation. J Oral Maxillofac Surg (2006) 64:1498-505. doi:10.1016/j.joms.2006.03.028

85. Farhadieh RD, Gianoutsos MP, Yu Y, Walsh WR. The role of bone morphogenetic proteins BMP-2 and BMP-4 and their related postreceptor signaling system (Smads) in distraction osteogenesis of the mandible. J Craniofac Surg (2004) 15:714-8. doi:10.1097/00001665-200409000-00003

86. Kasaai B, Moffatt P, Al-Salmi L, Lauzier D, Lessard L, Hamdy RC. Spatial and temporal localization of WNT signaling proteins in a mouse model of distraction osteogenesis. J Histochem Cytochem (2012) 60:219-28. doi:10.1369/ 0022155411432010

87. Makhdom AM, Rauch F, Lauzier D, Hamdy RC. The effect of systemic administration of sclerostin antibody in a mouse model of distraction osteogenesis. J Musculoskelet Neuronal Interact (2014) 14:124-30.

88. Morse A, McDonald M, Kelly N, Melville K, Schindeler A, Kramer I, et al. Mechanical load increases in bone formation via a sclerostin-independent pathway. J Bone Miner Res (2014) 29(11):2456-67. doi:10.1002/jbmr.2278

Conflict of Interest Statement: The authors declare that the research was conducted in the absence of any commercial or financial relationships that could be construed as a potential conflict of interest.

Received: 16 September 2014; accepted: 26 November 2014; published online: 10 December 2014

Citation: Alzahrani MM, Anam EA, Makhdom AM, Villemure I and Hamdy RC (2014) The effect of altering the mechanical loading environment on the expression of bone regenerating molecules in cases of distraction osteogenesis. Front. Endocrinol. 5:214. doi: 10.3389/fendo.2014.00214

This article was submitted to Bone Research, a section of the journal Frontiers in Endocrinology.

Copyright (C) 2014 Alzahrani, Anam, Makhdom, Villemure and Hamdy. This is an open-access article distributed under the terms of the Creative Commons Attribution License (CC BY). The use, distribution or reproduction in other forums is permitted, provided the original author(s) or licensor are credited and that the original publication in this journal is cited, in accordance with accepted academic practice. No use, distribution or reproduction is permitted which does not comply with these terms. 